\title{
Control of stress-strain state in double-span reinforced concrete beams
}

\author{
Nataliya Statsenko, ${ }^{1, *}$, and Valery Mitasov ${ }^{1}$ \\ ${ }^{1}$ Novosibirsk State University of Architecture and Civil Engineering (Sibstrin), 630008 Novosibirsk, \\ Russia
}

\begin{abstract}
Considering the tendency of reinforced concrete to redistribute load depending on the amount and location of effective reinforcement a series of experiments were performed using a non-traditional approach with set strain behavior of reinforced concrete beams during crack formation. The influence of location and number of cracks on load redistribution in double-span reinforced concrete beams was assessed. During the experiments comparative analysis of moments at support and at span was performed using uniform method of experiment. The paper presents mechanisms of load redistribution caused by non-linear deformations of a cracked element and plastic properties of compressed concrete.
\end{abstract}

\section{Introduction}

The peculiarity of RC structures strain in statically indeterminate systems is the ability of self-regulation of stress-strain state depending on the actual load. This is well demonstrated in design of flat RC cast-in-place ribbed floorings with beam elements, when reinforcement of multispan beam elements leads to formation of plastic hinges and allows using schemes with equal moments. In fact, we control stressed state of a RC structure by installation of reinforcement in multispan beam or plate structural systems. Such techniques are widely used in design and civil engineering. However, reinforcement is not the only stress state regulator .

Krasnoyarsk scientific school founded by N. Abovsky and including such scientists as L. Endzhievsky, V. Savchenkov, A. Deruga, N. Marchuk, G. Sterekhova, V. Palagushkin, N. Andreev, P. Svetashkov, O. Maksimova, etc., have been studying the influence of various regulation parameters on stress-strain state of structures for many years. Sources [14] formulate the principles for creation of automatic control system for stress-strain state based on system approach to the controlled structure design with consideration of internal actions and energy required for managing.

Vast experimental and theoretical material has been accumulated on investigation of load redistribution and bearing capacity of statically indeterminate structures with consideration of plastic properties of reinforcement and concrete [5-13]. It is obvious that

\footnotetext{
Corresponding author: stacnat@yandex.ru
} 
both theory and practice of RC construction impose the necessity of such approaches for designing RC structural systems.

While working on the energy theory of reinforced concrete and a new end-to-end method of reinforced concrete analysis based on energy diagram method [14-16], practicality of cracks generation while producing $\mathrm{RC}$ structures was proved both theoretically and experimentally.

Experimental results for pre-cracked beams showed that such cracks serve for internal control of stress-strain state. This finding opens new perspectives for further extension of reinforced concrete theory and practice which are based on energy theory of reinforced concrete resistance.

The purpose of the research, thus, is to assess the effect of number and location of precracks on load redistribution in double-span reinforced concrete beams.

\section{Experiment}

In recent years, the orientation for providing seismic resistance of buildings and structures has evolved in the CIS and other countries. It is characterized by the development of active seismic protection and isolation systems, the use of which allow managing within certain limits the regulation of stresses in buildings and structures during earthquakes [17-19].

Regulation (redistribution) of load in reinforced concrete structures ensures their normal functioning in varied operating conditions. The task of regulation consists in prior redistribution of load to provide favorable state for certain operating conditions.

Program of experiments was developed for studying the peculiarities of strain processes and crack formation processes in beams with solid cross-sections and in pre-cracked beams. During the experiments comparative analysis of stress-strain state of the above-mentioned beams was performed using uniform method of experiment.

Specimens preparation. Four series of double-span RC beams with rectangular crosssection $(b=100 \mathrm{~mm}, \mathrm{~h}=200 \mathrm{~mm})$ were prepared for the experiments (Table 1$)$, three out of the four series consisted of pre-cracked beams of different types.

Beams were reinforced with a flat steel frame. The frame consists of longitudinal principal rebars of A-400 type $6 \mathrm{~mm}$ in diameter and transverse rebars of A-240 type $6 \mathrm{~mm}$ in diameter placed with the pitch of $80 \mathrm{~mm}$. Reinforcement ratio is $\mu=0.15 \%$.

All specimens were produced of fine grained concrete with the components ration of 1:2.5 (cement of type M400:sand) with $\mathrm{W} / \mathrm{C}=0.45$ and filler fineness modulus of $2.5-5 \mathrm{~mm}$, filler strength corresponding to the type B20.

Reference prisms $100 \times 100 \times 400 \mathrm{~mm}$ in size and cubes $100 \times 100 \times 100 \mathrm{~mm}$ in size were prepared and tested along with experimental specimens using the П-250M hydraulic press to define the strength of concrete. Prism strength values for fine grained concrete in experimental specimens during testing are given in Table 1.

Table 1. Program of experiment.

\begin{tabular}{|c|c|c|c|}
\hline $\begin{array}{l}\text { Beam } \\
\text { reference }\end{array}$ & \multirow{2}{*}{ Scheme of pre-cracks } & \multirow{2}{*}{$\begin{array}{l}\text { Longitudinal } \\
\text { reinforcement, } \\
\frac{\underline{\mathrm{d}}_{\underline{\mathrm{s}}} \mathrm{mm}}{\mu, \%}\end{array}$} & Prism strength \\
\hline number & & & $\begin{array}{l}\text { Cross-section } \\
\text { diameter, mm }\end{array}$ \\
\hline Б-1-1a & $F$ & & \\
\hline Б-1-16 & & $\frac{\emptyset 6}{0,15}$ & $\frac{16.22 \mathrm{MPa}}{100 \times 200}$ \\
\hline Б-1-1в & $\begin{array}{c}140,400 \times 400 \\
2200\end{array}$ & & \\
\hline
\end{tabular}




\begin{tabular}{|c|c|c|}
\hline Б-2-2a & $F$ & \multirow{4}{*}{$\frac{14.5 \mathrm{MPa}}{100 \times 200}$} \\
\hline Б-2-2б & \multirow{3}{*}{$\frac{140 \times 480 \times 480 \times 480 \times 480 \quad 740}{2200}$} & \\
\hline & & \\
\hline Б-3-3в & & \\
\hline Б-3-3a & \multirow{3}{*}{$140,480 \times 480 \times 480 \times 480 \quad 140$} & \multirow{3}{*}{$\frac{17.72 \mathrm{MPa}}{100 \times 200}$} \\
\hline Б-3-3б & & \\
\hline Б- $3-3 в$ & & \\
\hline Б-5-5a & $F$ & \multirow{3}{*}{$\frac{17.23 \mathrm{MPa}}{100 \times 200}$} \\
\hline Б-5-5б & 8 & \\
\hline Б-5-5в & $\begin{array}{c}140 \times 480 \times 480 \\
2200\end{array}$ & \\
\hline
\end{tabular}

Beam identification code: first letter «Б» stands for "beam". First digit marks the series, the second digit marks the variant of pre-cracks location: 1 - beams with solid crosssections, 2 - beams with pre-cracks in mid support, 3 - beams with two pre-cracks in the middle of each span, 5 - beam with one pre-crack in the middle of one span (Table 1). Precrack was organized by installing a steel zink-coated plate $100 \times 60 \mathrm{~mm}$ in size and $0.3 \mathrm{~mm}$ wide.

Loading was performed by applying two concentrated forces, one force for each span at the distance of half of the span. Considering this loading scenario, the ratio of support moment to the span moment defined from the elastic system is $\mathrm{M}_{\mathrm{sup}} / \mathrm{M}_{\mathrm{sp}}=1.2$. For the purpose of load redistribution due to pre-cracks formation and opening, reinforcement of support and span cross-section was installed according to elastic system calculation. Practically it was achieved by setting the same amount of reinforcement in support and in span.

The load was transmitted to the beam through a pin-supported crossbar. The load was sustained for 15 minutes at each stage, during that time the readings of sensors were recorded and the pre-cracks opening width was measured.

The moment of cracks formation, their propagation pattern in height and opening width were recorded visually and using the МПБ- 2 microscope with the scale of $0.05 \mathrm{~mm}$. The width of regular cracks was measured at the level of tensile reinforcement. During pauses between loading sessions, the height, width and propagation pattern of cracks at a certain loading state were marked on the bleached side surface of the beam.

Concrete strain and beam deflection were measured up to bearing capacity exhaustion, which corresponded to the yield stress in reinforcement and further crush of beam concrete in the compression area.

\section{Results}

All beams were tested using a uniform technique. As a result of the experiments, comparative data were obtained on deformation of beams with different variants of precracks location.

Moment values for support reactions in beams with pre-cracks were found different from those obtained for elastic deformation scheme. This difference was equally observed 
for all beams series almost from the initial loading stages, which corresponds to formation of stochastic cracks or to opening of pre-cracks in span or support beam cross-sections. Figure 1 presents graphs of support moments and span moments variation for 4 beam series. The graphs also include the values of moments obtained from both experiments and elastic deformation calculation.

a)

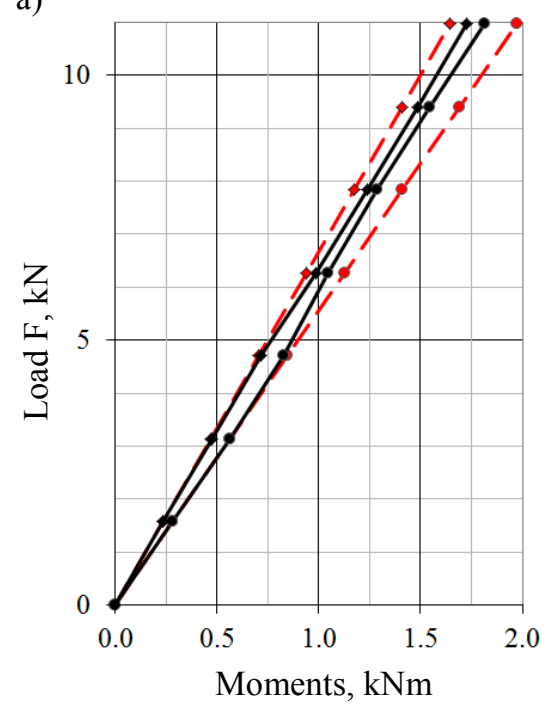

c)

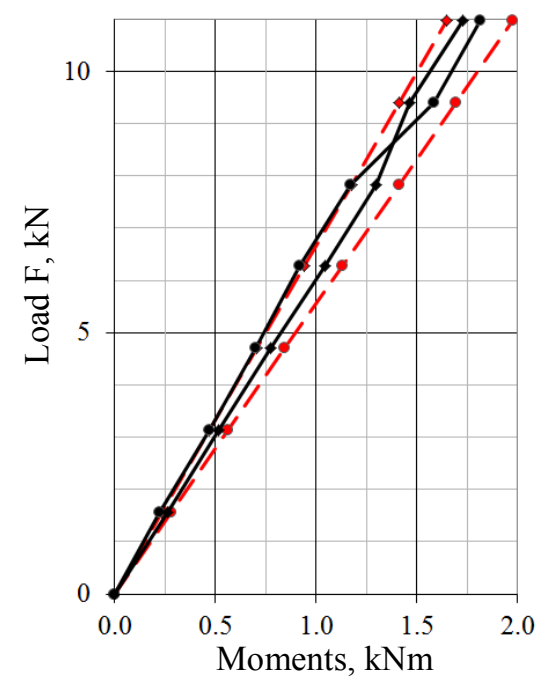

b)

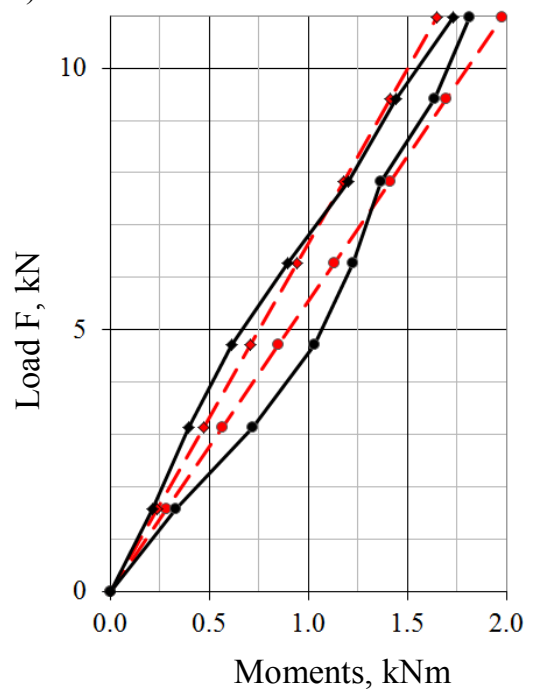

d)

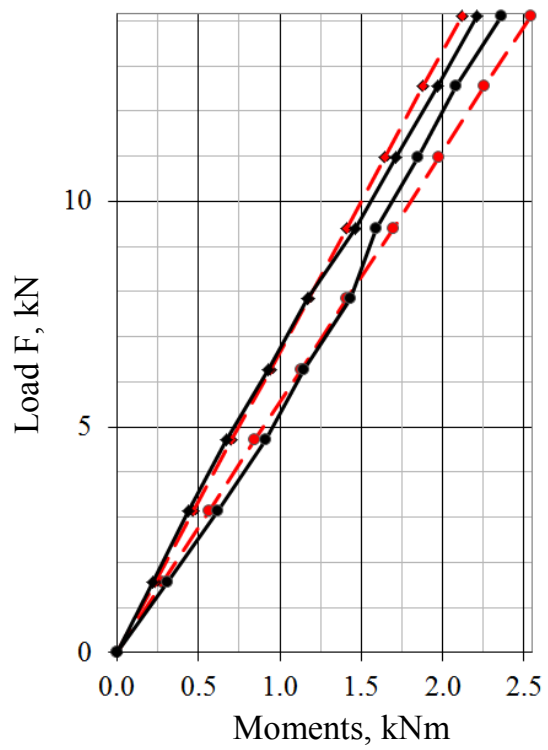

$\rightarrow \mathrm{M}_{\text {support }}$ for elastic deformation calculation

$\rightarrow \therefore \mathrm{M}_{\mathrm{span}}$ for elastic deformation calculation

$\rightarrow M_{\text {support }}$ for experiment

$\rightarrow M_{\text {span }}$ for experiment

Fig. 1. Span and support moments in beams: a) with solid cross-section; b) with two pre-cracks in each mid-span; c) with a pre-crack in mid-support; d) with one pre-crack in the middle of the first span. 
Having analyzed the obtained graphs, one can notice that under low loads (loading stage 1-3) the experimental values for beams series 1,2 and 5 correspond closely to the calculated ones. With stochastic cracks occurring or pre-cracks opening, experimentally obtained moment values differ a lot from those calculated for elastic deformation scenario.

Considering redistribution of load after stochastic cracks occurrence or pre-cracks opening, the value of support moment under load $F=14 \mathrm{kN}$ in each span was $\mathrm{M}=2.36 \mathrm{kNm}$ for beam series $1,2,5$ and $\mathrm{M}=1.878 \mathrm{kNm}$ for beam series 3 , which is significantly lower than the limit value $\mathrm{M}=2.54 \mathrm{kNm}$. The moment at support reached the value of $2.54 \mathrm{kNm}$ under the load in span roughly equal to $\mathrm{F}=16 \mathrm{kNm}$. As a result of formation and opening of cracks in beam series 1, 2, 5 due to redistribution of loads compared to elastic deformation scenario the load at which support cross-section reaches its limit state increased by $14 \%$.

The results of RC beams testing were used to obtain graphs of midspan deflection (Fig. 2).

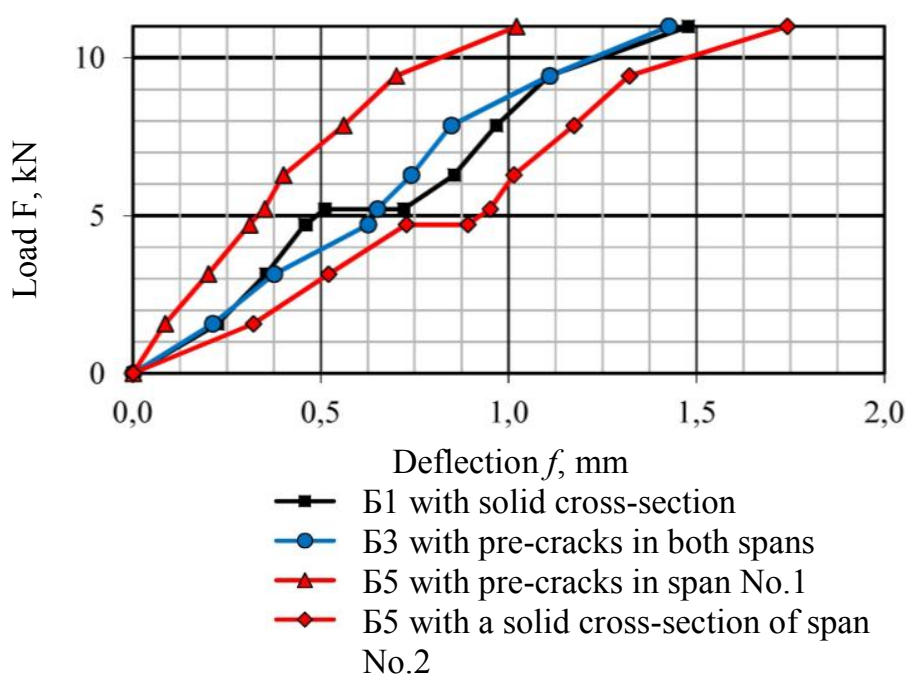

Fig. 2. Graph of dependence of deflection f on load F.

The load-deflection curve for beams with solid cross-section in span has a clearly visible region of deflection growth under permanent load, while in pre-cracked beams such regions are not observed. The maximum deflection in span is $1.48 \mathrm{~mm}$ with the load of 11 $\mathrm{kN}$ in each mid-span.

The following was found for pre-cracked beams:

- In beams with pre-cracks in each mid-span the deflection at initial stage is higher that that in beams with solid cross-section. Slight variation of the curve and transition to the region of less growth correspond to opening and propagation of pre-cracks. The maximum deflection is $1.43 \mathrm{~mm}$ with the load of $11 \mathrm{kN}$ in each mid-span.

- In beams with a pre-crack in the middle of span No.1 the values of deflection in each mid-span differ considerably, approx. by 2.7 times. Deflections in the second span are higher than in beams with solid cross-section. However, the deflection values in span No.1 compared to those in beams series 1 is $45 \%$ lower. Maximum deflection in the first span is $1.02 \mathrm{~mm}$, in the second span $-1.74 \mathrm{~mm}$ under the load of $11 \mathrm{kN}$ in the mid-span.

Generation and opening of pre-cracks considerably varies load distribution compared to that within elastic system calculation, which indicates the regulatory function of pre-cracks. 
The conducted research serves as transition to regulation of deformation in reinforced concrete beams, and in prospect it will allow managing crack resistance by pre-cracks generation.

\section{Conclusion}

General approach for pre-cracks generation in frame systems is developed. The number and location of such cracks are proved to have direct effect on load redistribution and stressstrained state.

At the moment, full-scale experiments are being prepared with structures (reinforced concrete hollow-core flooring slabs) damaged up to serviceability limit state with precracks in the maximum moment area.

The suggested method of "plastic hinges" creation by cracks generation will allow using them as energy sinks.

In the beginning of 2018, dynamic experiments with RC frames prepared in scal 1:2 are planned in Kazakh State Research and Experimental Design Institute on Earthquake Engineering and Architecture. Such experiments will allow developing recommendation on the use of new energy sinks in buildings and structures located in seismic regions.

\section{References}

1. N.P. Abovsky, Upravljaemye konstrukcii [Controllable structures] (KrasGASA Publ., Krasnoyarsk, 1998) (in Russian)

2. A.A. Krasovsky, Spravochnik po teorii avtomaticheskogo upravlenija [Handbook on the automatic control theory] (Science, Moscow, 1987) (in Russian)

3. L.V. Endzhievskiy, Upravljaemye konstrukcii. [Controllable structures. Scientific educational complex] (KrasGASA, Krasnoyarsk, 2001) (in Russian)

4. N.P. Abovsky, Sovremennye aspekty aktivnogo obuchenija. Stroitel'naja mehanika. Teorija uprugosti. Upravlenie stroitel'nymi konstrukcijami [Modern aspects of active learning. Structural mechanics. Elasticity theory. Structural control] (Sib. feder. un-t, Krasnoyarsk, 2008) (in Russian)

5. S.M. Krylov, Pereraspredelenie usilij v staticheski neopredelimyh zhelezobetonnyh konstrukcijah [Redistribution of forces in statically indeterminate reinforced concrete structures] (Stroiizdat, Moscow, 1964) (in Russian)

6. Rukovodstvo po raschetu staticheski neopredelimyh zhelezobetonnyh konstrukcij. ed. by L.G. Bal'yan [Guide on the calculation of statically indeterminate reinforced concrete structures] (Strojizdat, Moscow, 1975) (in Russian)

7. N.I. Karpenko, Obshhie modeli mehaniki zhelezobetona [General models of reinforced concrete mechanics] (Stroiizdat, Moscow, 1996) (in Russian)

8. S. Kumaraswamy, IOSR-JMCE, 6, 38-43 (2013)

9. M. Leps, M. Sejnoha, Computers \& Structures, 81, 18-19 (2003)

10. M.N.S. Hadi, L.C. Schmidt, International Journal of Materials \& Product Technology, 19, 3-4 (2003)

11. S.-S. Lu, W.-Z. Zhen, Journal of Harbin Institute of Technology (New Series), 17, 4 (2010)

12. Z.P. Bazant, Journal of Structural Engineering, 110, 2015-2036 (1984)

13. H. Akbarzadeh, A.A Maghsoudi, Mater Des, 31(3), 1130-1147 (2010)

14. V.M. Mitasov, Osnovnye polozhenija teorii soprotivlenija zhelezobetona [The basic provisions of the theory of reinforced concrete resistance] (NGASU (Sibstrin), Novosibirsk, 2010) 
15. V.M. Mitasov, V. Adishev, M.A. Logunova, Proceedings of the International Scientific Conference "Modern Construction Science, State and Development Prospects", 50-53 (Alma-Ata, October 27-29, 2016)

16. V.M. Mitasov, M.A. Logunova, Proceedings of the International Scientific Conference "Science, Technical Management and Engineering in Construction: State and Prospects", 271-273 (Karaganda, April 29-30, 2016) (in Russian)

17. N.V. Martynov, Aktivnaja sejsmozashhita: varianty razvitija $i$ kriticheskij analiz prakticheskih vozmozhnostej [Active earthquake protection: options for development and critical analysis of practical possibilities] (monograph, Simferopol, 2013) (in Russian)

18. V.M. Mitasov, V. Adishev, N.V. Statsenko, Proceedings of the International Scientific Conference "New building trends in the XXI century", 18-21 (Almaty, June 27, 2017) (in Russian)

19. E.K. Nurmagambet, Sooruzhenija v ekstremal'nyh uslovijah [Constructions under extreme conditions] (KazNTU, Almaty, 2005) (in Russian) 